\title{
POTENTIAL HYDROLOGIC EFFECTS OF PEAT MINING IN THE RED LAKE PEATLANDS, NORTH-CENTRAL MINNESOTA- A PROJECT PLAN
}

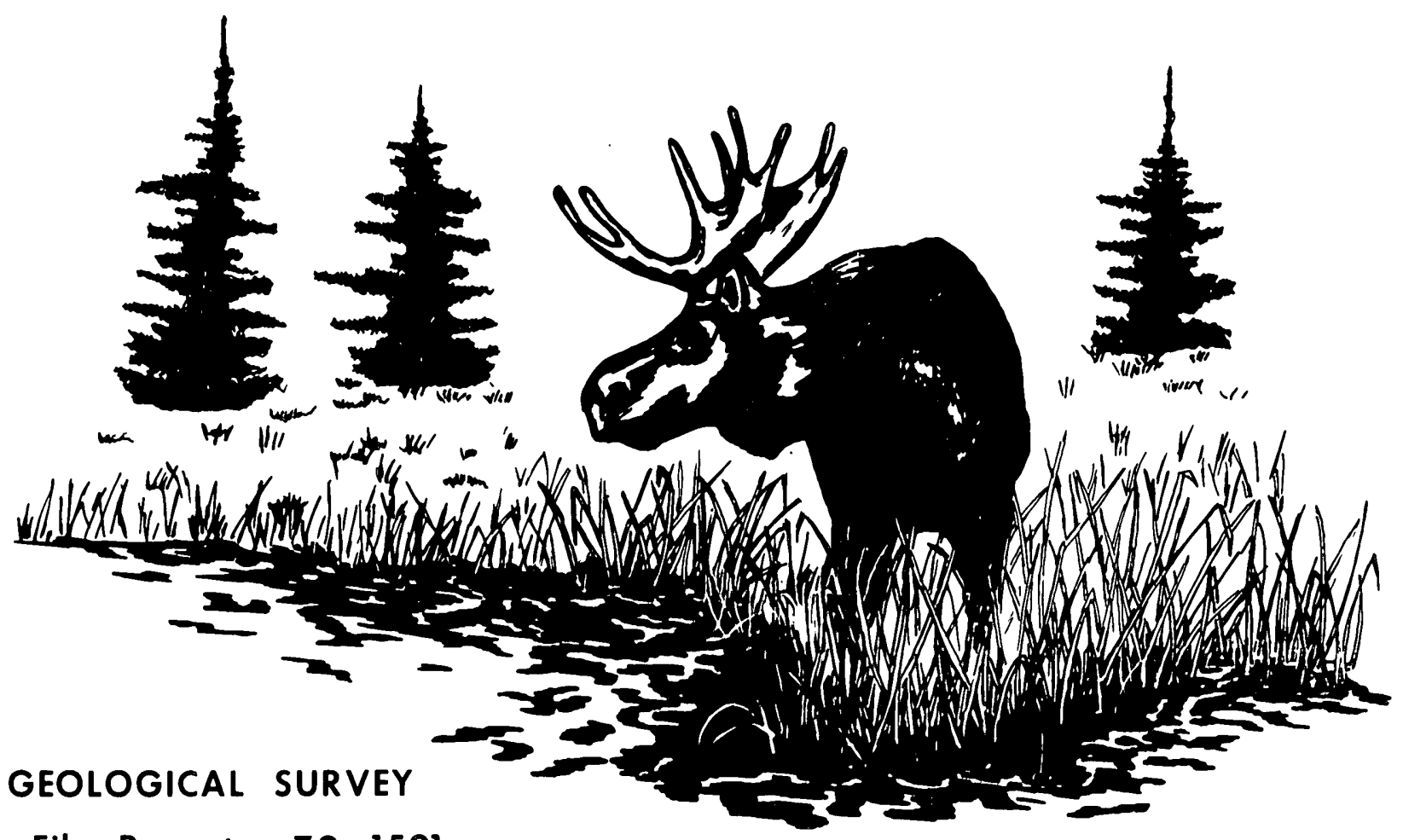

Open-File Report 79-1591

Prepared in cooperation with the Minnesota Department of Natural Resources

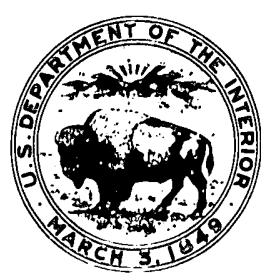




\section{UNITED STATES \\ DEPARTMENT OF THE INTERIOR \\ GEOLOGICAL SURVEY}

POTENTIAL HYDROLOGIC EFFECTS OF PEAT MINING IN THE

RED LAKE PEATLANDS, NORTH-CENTRAL MINNESOTA--

A PROJECT PLAN

By D. I. Siegel

Open-File Report

Prepared in cooperation with the

Minnesota Department of Natural Resources

St. Paul, Minnesota

December 1979 
Conversion factors....................................... ii

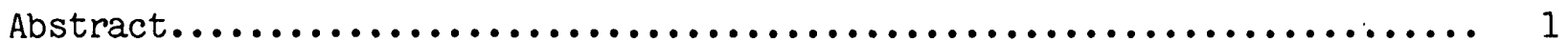

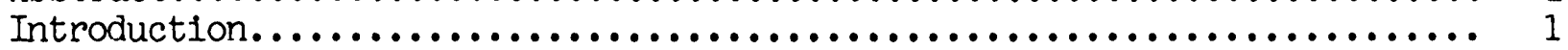

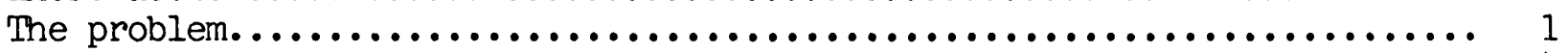

Objectives..............................................

Approach................................................

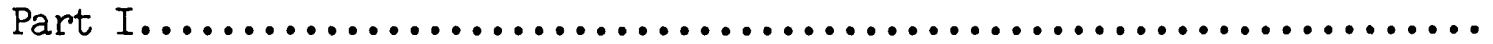

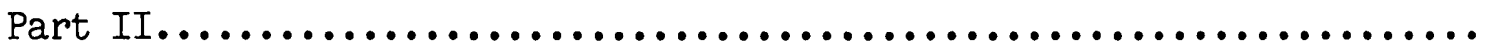

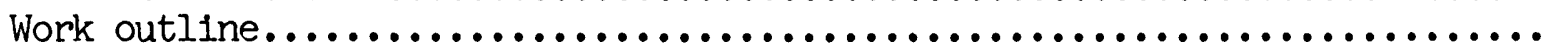

References cited.

\section{ILLUSTRATIONS}

Figure 1. Proposed study area and stream and precipitation gage

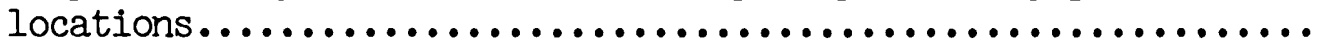

2. Approximate location of test holes in and around the Tamarac River watershed.

Multiply

inch-pound units

foot (ft)

mile ( $\mathrm{ml}$ )

acre

cubic foot per day $\left(f t^{3} / d\right)$
By

0.3048

1.609

0.4047

0.02832
To obtain SI units

meter (m)

kilometer $(\mathrm{km})$

square hectometer $\left(\mathrm{hm}^{2}\right)$

cubic meter per day $\left(m^{3} / d\right)$ 
POTENIIAL HYDROLOGIC EFFECTS OF PEAT MINING IN THE RED

LAKE PEATLANDS, NORTH-CENTRAL MINNESOTA--

A PROJECT PLAN

By Donald I. Siegel

\begin{abstract}
Peat is being considered for fuel in Minnesota. This study will investigate the potential effects of large-scale surface mining of peat on the hydrology and water quality of Upper Red Lake and the Tamarac River. The major aspects of the study are the characterization of the surface-water and groundwater hydrology and water quality, including the trace-metal content of the peat. Data will be collected to construct two and three-dimensional digital models to simulate the movement of ground water and its relation to surface water in the peatlands, streams, and lakes. After the model is calibrated with field data, it will be used to evaluate the effect of mining peat on the hydrology and water quality of the Upper Red Lake and Tamarac River.
\end{abstract}

\title{
INTRODUCTION
}

As petroleum and natural gas reserves decline, peat is being given more consideration as fuel. Minnegasco, a major utility company in Minnesota, has applied for leases to mine peat from about 200,000 acres of the State's 7.5 million acres of peatland. A gasification plant is planned to convert the peat to methane at a rate of 250 million cubic feet per day, which is about one-fourth of Minnesota's current daily consumption of natural gas.

Surface mining of peat is planned in Beltraml, Koochiching, and Lake of the Woods Counties, northern Minnesota. The area includes private, State, and Federal lands and part of the Red Lake Indian Reservation owned by the Chippewa Tribe. The Tamarac River drains the Red Lake Peatlands to Red Lake, which is important to the Indians as a fishery. The Black and Rapld Rivers drain the peatlands north to the Rainy River, which borders Canada (flg. 1).

\section{THE PROBLEM}

Little is known about surface water and ground water or about the chemical quality of water in the Red Lake Peatlands. State and Federal agencies and the Chippewa Tribe are concerned about the effects of peat mining on the Lake of the Woods and Tamarac River watersheds. Hydrologic or water-quality changes in the Lake of the Woods watershed would impact both United States and Canadian waters, and changes in the Tamarac River watershed would quickly impact Upper Red Lake in the reservation. 


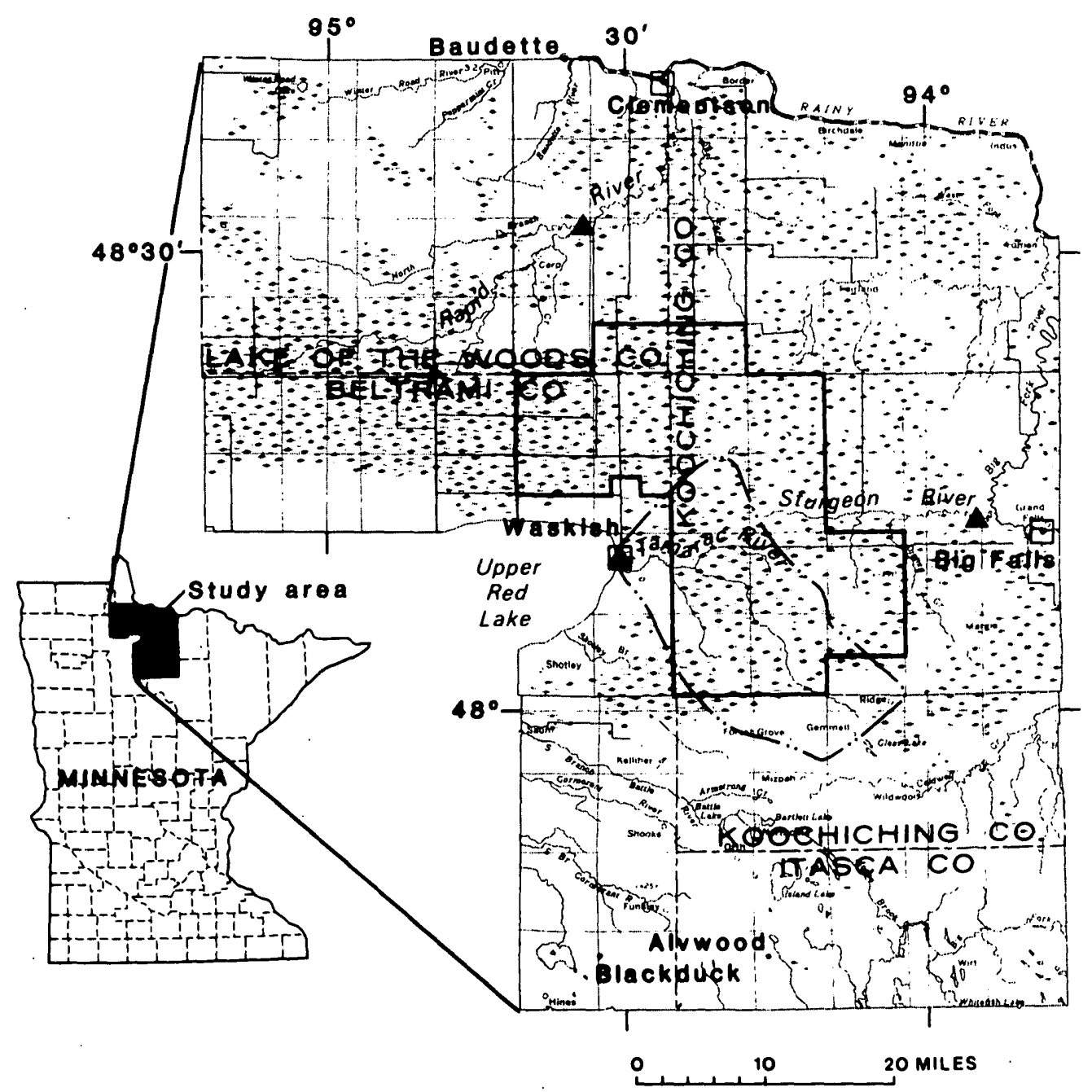

EXPLANATION

Continuous recording stream gage

Continuous recording precipitation gage
Approximate watershed divide of the Tamarac River above Waskish

Boundary of the proposed surface mining of peat 
The area proposed for surface mining (fig. 1) lies within the large wetlands formed in an area previously occupied by glacial Lake Agassiz. Deposits of calcareous lake clay, reworked outwash, and till underlie the peat. Sand and gravel beach ridges trend east-west across the area.

Data on the hydrology and geology are mostly related to peatland ecology. Heinselman (1963) described the vegetation patterns and evolution of the Red Lake Peatlands in the northern and central part of the proposed mining area. Heinselman (1970) also devised a peatland classification according to physiographic location, water-table conditions, vegetation, and water quality. This classification has provided the framework for peat inventories and reconnaissance mapping of vegetational patterns and surfictal geology (Eng, 1976; Fox and others, 1977). These and similar studies north of Upper Red Lake (Farnharn and Grubich, 1966) provide general data on the distribution of peat types and the range of peat thickness. Surface-water investigations (Bidwell and others, 1970; Helgesen and others, 1975; Lindholm and others, 1976) of the Red Lake, Rainy River, and Big Fork River watersheds include reconnaissance hydrologic and water-quality data on the Tamarac, Sturgeon, and Rapid Rivers. The hydrology of small peatlands in other parts of the State has been investigated in some detail (Boelter and Verry, 1977), but it is uncertain if the Red Lake Peatlands offer an analagous situation.

The ground water beneath the peatlands has not been investigated. However, it has been suggested by Helnselman (1970) and by Boelter and Verry (1977) that ground-water discharge is one factor that may explain the "water tracks" and vegetational and chemical quality of water differences in the Red Lake Peatlands. In particular, ground-water discharge may partly control the location of reedsedge fens, which contain water having a higher $\mathrm{pH}$ and a greater concentration of calcium, magnesium, and sodium than water in raised sphagnum bogs.

The effects of peat mining on the chemical quality of surface water needs investigation because nutrients and trace metals may be released to surfacewater systems during the mining. Recent studies (Crawford, 1978) suggest that organic-rich water typical of peatlands promotes rapid algal growth in lakes and that peat can contain concentrations of potentially toxic metals, such as mercury, at the parts-per-million level. Mercury and possibly other metals introduced to the lake environment can be methylated by bacteria to soluble forms. Humic acids commonly found in peat water have the capacity to mobilize trace metals. Natural background levels of these metals need to be determined to assess the potential for metal transport from the peatlands by the Tamarac River into Upper Red Lake and by the Sturgeon and Black RIvers into Lake of the Woods. Of the three rivers, the Tamarac would be most impacted by peat mining because much of its watershed lies within the proposed mining area. Water quality or hydrologic changes caused by peat mining could quickly affect Upper Red Lake, which is at the mouth of the Tamarac River. 


\section{OBJECTIVES}

The objectives of the proposed study are to determine (1) the hydrology of the Red Lake Peatlands at a reconnaissance level and of the Tamarac River watershed in detail, (2) the water qual1ty of the Sturgeon, Rapid, and Tarnarac Rivers, and (3) the potential effects of surface mining of peat on the water quality, surface-water hydrology and ground-water hydrology in the Tarnarac River watershed in particular, and watersheds of the Rapid and Sturgeon Rivers in general.

\section{APPROACH}

Work on the project will be divided into two major parts, and several reports will be prepared for each.

\section{Part I}

A literature search will be made of the hydrology of peat in both natural systems and in systems disturbed by mining. A preliminary assessment of the hydrology of the Red Lake Peatlands will be made from data and information obtained from publications by the Minnesota Department of Natural Resources (MDNR), University of Minnesota, U.S. Forest Service, U.S. Bureau of Mines, U.S. Geological Survey, and technical joumals.

With the aid of avallable meteorologic and geohydrologic data, twodimensional, numerical, cross-section models will be constructed to aid conceptualization of the ground-water flow system. The cross sections will be along north-south traverses from the major recharge area, the Itasca Moraine, to the major surface-water divides. The first traverse will be north from Blackduck to near Baudette on the Rainy River (fig. 1) and will cross part of Upper Red Lake, the pattermed peatlands north of Upper Red Lake, and the major surfacewater divide between the Lake of the Woods and the Red River watersheds. The traverse crosses several beach ridges, areas of lake-washed ground moraine, and several teardrop vegetational patterns typical of the patterned peatlands.

The second traverse will extend from near Alvwood to the northernmost extent of the surface-water divide of the Tamarac River (fig. 1). This traverse will cross several beach ridges and the patterned fens in the headwaters of the Tamarac River.

Results from the cross-section models will be used, in part, to locate 20 to 30 test holes along each traverse at about 1 -mile intervals (fig. 2). Half the test holes will be drilled from 200 to 350 feet to bedrock or other hydrologic unit with low permeability to define the lower boundary of the regional flow systems. Depending on the initial geologic data, the remaining test holes w11l be drilled 50 to 100 feet deep below the peat. Piezometer nests w1ll be completed at 10 sites along each traverse to determine vertical head gradients. At each of these sites, plezometers will be installed in the peat, in the material immediately underlying the peat, and in all significant geohydrologic units identified in the test drilling. 


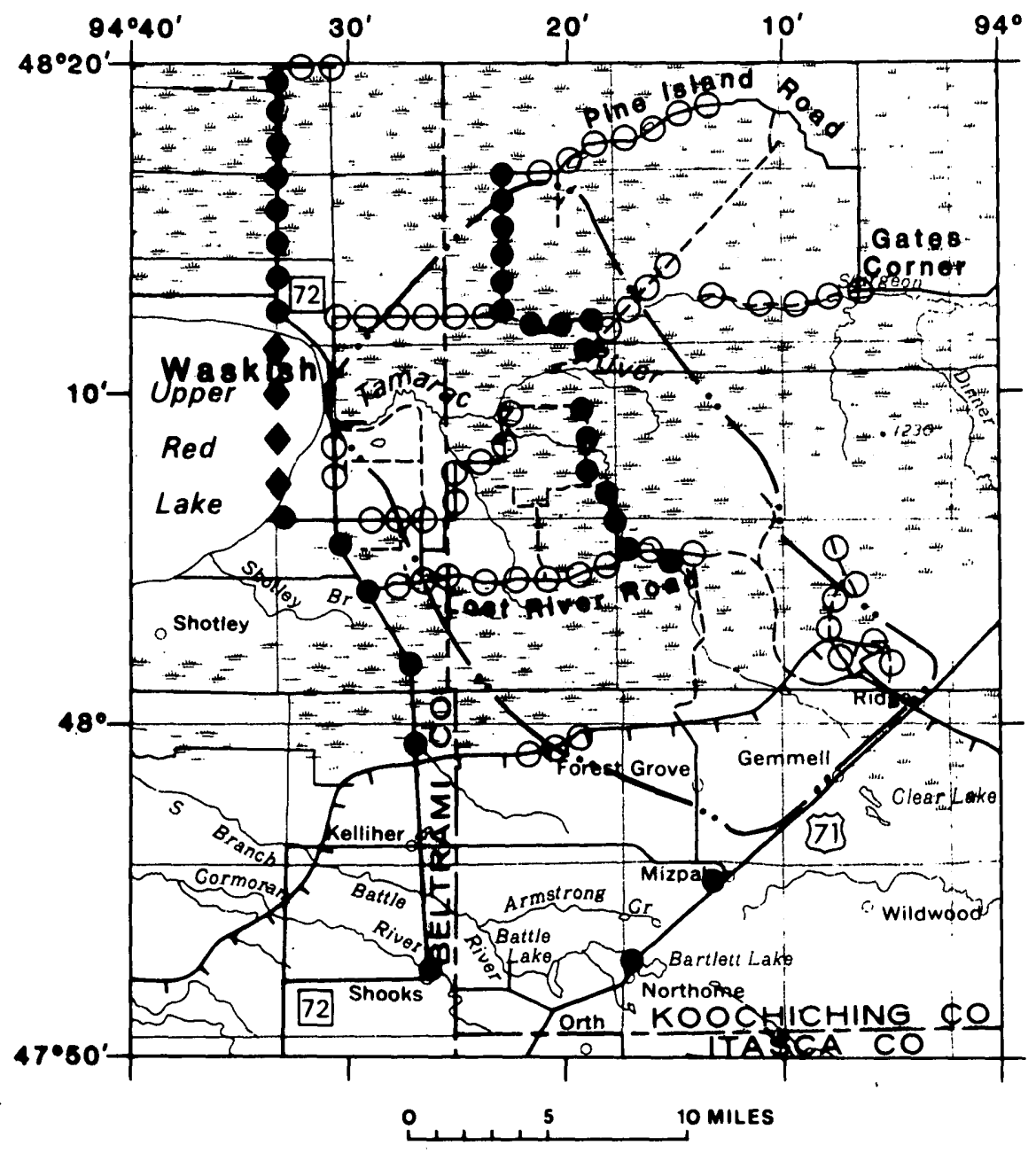

EXPLANATION

Approximate test hole

- locations-first part of the project

Approximate test hole

O locations-second part of the project

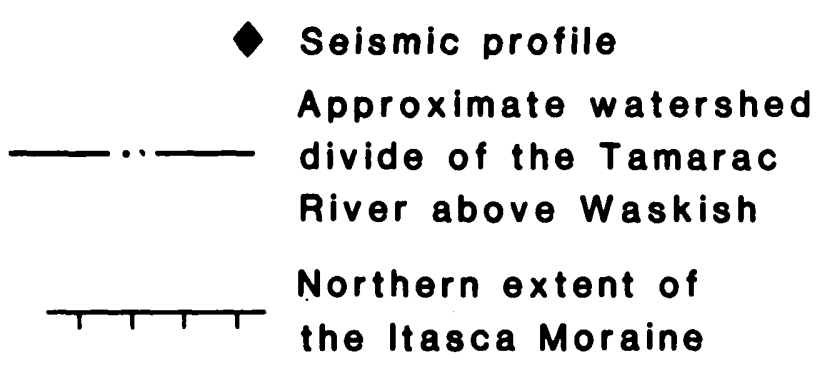

Seismic profile

Approximate watershed divide of the Tamarac River above Waskish the Itasca Moraine

\footnotetext{
Note: Test holes to be drilled in the first part near Baudette end and on the Itasca Moraine are deleted from the figure
} 
Samples (100-gram) of both hemic and sapric peat will be collected at each drilling location and analyzed for total mercury, copper, nickel, arsenic, cobalt, lead, and cadmium. Samples of the saturated peat will be compressed and the effluent analyzed for major cations, sulfate, chloride, sulfide, pH, silica, dissolved solids, specific conductance, DOC (dissolved organic carbon), and the same trace metals analyzed in the peat material. Results of the analyses of the compressed-peat effluent and peat material will determine if mining of the peat by methods such as hydraulic dredging could mobilize trace metals into the water system. Shallow seismic profiles will be run across the eastern part of Upper Red lake to determine total sediment thickness under the lake.

Water levels will be measured continuously for 1 year at a piezometer nest on the Itasca moraine, at two locations on beach ridges or lake-washed moraines, and at four locations in discharge areas in the peatlands. Water levels in all other plezometers will be measured quarterly to determine seasonal fluctuations in head. Water samples will be collected quarterly from 20 piezometers to char acterize ground-water quality in the peat and in underlying material. Analyses will be for major cations and anions, silica, total phosphorus, Kjeldahl nitrogen, $\mathrm{pH}, \mathrm{DOC}, \mathrm{TOC}$ (total organic carbon), specific conductance, Eh, and dissolved mercury, cobalt, cadmium, chromium, copper, nickel, iron, manganese, nickel, zinc, lead, and arsenic.

Daily precipitation data will be collected from U.S. Weather Bureau gages at Clementson and $\mathrm{Big}$ Falls and at a continuously recording precipitation gage to be installed at Waskish ( $\mathrm{flg}$. 1). Evapotranspiration from the peatlands will be estimated by the Thorthwaite method (Bay, 1967).

Continuously recording stream gages will be installed and maintained for 1 year at the mouth of the Tamarac River, which drains mostly peatlands; the Sturgeon River, which drains peatlands and a significant area of beach ridges and lake-washed ground moraines; and the Rapid River, which partly drains the forest island and fen complex north of Upper Red Lake. The daily hydrographs of these streams and the analysis of previous records of the Rapid River will characterize the response of peatland and associated watersheds to precipitation and to seasonal climatic trends recorded at the rain gages.

The results from the test drilling, selsmic work, water-level measurements, precipitation data, streamflow data, and evapotranspiration calculations will be used to (1) refine and calibrate the two-dimensional, conceptual crosssection models of the ground-water flow system across the patterned peatlands and the Tamarac River watershed, and (2) calculate a yearly water balance for the peatlands.

Water samples will be collected monthly frorn streams at the gaging stations and at one headwater location on each stream. These surface-water samples will be analyzed for the same constituents as the ground-water samples. Discharge measurements will be made concurrently with collection of the samples for chemical analysis. The concentration and discharge data will be used to estimate the yearly net losses of major cations, trace metals, and nutrients from the three watersheds. Seasonal variations in concentration will be correlated with discharge. Water-quality differences between the streams will be tested for statistical significance and related to watershed geology and peat types. 
A report will be prepared at the conclusion of this phase that will (1) describe the subsurface geology, ground-water flow system, and chemical quality of ground water along the transect lines across the peatlands, (2) characterize the flow and chemical quality of the Tamarac, Sturgeon, and Rapid Rivers, (3) describe the trace-metal content of the peat and of effluent from compressed peat, and (4) compare the chemical quality of water from streams, aquifers, and peat.

\section{$\underline{\text { Part II }}$}

Measurements of flow and water levels will be continued for another year to enlarge the data base and to provide data for comparison with data obtained in Part $I$. Water samples will be collected quarterly during the additional year to determine if waterquality trends observed in Part I continue.

From 25 to 50 test holes will be drilled and 10 to 20 piezometers installed along additional traverses ( $f 1 g .2$ ) to better define the hydrogeology of the Tamarac River watershed. Major traverses will extend east-west alons the Pine Island Road, Lost River Road, and along the Sturgeon River from Gates Comer across the peatlands to the Tamarac River.

Fifteen to 25 shallow test holes will be drilled and water-table piezometers installed along several short traverses (fig. 2) to better define the ground-water divide of the Tamarac River basin. Peat samples will be collected as in Part I and analyzed for trace-metal content. Water-level measurements will be made quarterly in the plezometers for a year to define fluctuations in the water table in the Tamarac River watershed and to provide data on shifts of the ground-water divide with seasonal fluctuations of the water table.

The test-hole information, evaporation and precipitation data, streamflow data, and water-table measurements collected in Part II will be used to construct a three-dimensional steady-state numerical model of the ground-water system in and around the Tamarac River watershed. The model will be used to Identify areas where more data are needed and to simulate the effects of stresses on the hydrologic system caused by peat removal. Current hydrologic studies by MDNR of small disturbed peatland watersheds will provide additional data. Results of the model analysis of the Tamarac River watershed and Upper Red Lake area will be applied to a general evaluation of peat mining in the Rapid River and Sturgeon River watersheds.

At the conclusion of Part II, a report will be prepared that will describe the (1) three-dimensional, steady-state numerical modeling of the Tamarac River watershed, (2) trace-metal content of peat in the watershed, and (3) probable effects of peat mining in the Tamarac River watershed particularly, and in the Rapid River and Sturgeon River watersheds, in general. 
WORK OUTLINE

I. First fiscal year

A. Part I

1. Preparation of ilterature review

2. Constmaction of conceptual two-dimensional ground-water flow models

3. Drilling of test holes and piezometer construction

4. Selsmic profile across Upper Red Lake

5. Stream and precipitation gage construction

6. Hydrologic, peat, and water-quality-data collection

II. Second fiscal year

A. Part I

1. Refinement of the two-dimensional numerical models

2. Preparation of progress report

3. Continuation of hydrologic and water-quality-data collection

B. Part II

1. Drilling of test holes and piezometer installation in the Tamarac River watershed

2. Hydrologic, peat-quality, and water-quality-data collection

3. Preliminary three-dimensional numerical ground-water-flow model of the Tamarac River watershed

III. Third fiscal year

A. Part II

1. Completion of hydrologic and water-quality-data collection

2. Geochemical analysis

3. Refinement of the three-dimensional numerical ground-water flow model

4. Preparation of the final report 
Bay, Roger R., 1967, Evapotranspiration from two peatland watersheds, from: "Geochemistry, Precipitation, Evaporation, Soil-Moisture, Hydrometry," General Assembly of Bern, 1967, p. 300-307.

Bidwell, L. E., Winter, T.C., and Maclay, R. W., 1970, Water resources of the Red Lake RIver watershed, northwestern Minnesota: U.S. Geological Survey Hydrologic Investigations Atlas HA-346.

Boelter, D. H., and Verry, E. S., 1977, Peatland and water in the northern lake states: U.S.D.A. Forest Service General Technical Report NC-31, 22 p.

Crawford, R. L., 1978, Effects of peat utilization on water quality in Minnesota: Final Report, March 1978, University of Minnesota, Freshwater Biological Institute, Nawarre, $18 \mathrm{p}$.

Eng, M. T., 1976, An aerial evaluation of peat resources, fen patterns, and other surficial deposits in Koochiching County, Minnesota: Minnesota Department of Natural Resources, Division of Minerals, 1:62:500.

Farmham, R. S., and Grubich, D. N., 1966, Peat resources of Minnesota: Report of Inventory no. 3, Red Lake Bog, Beltrami County, Minn., Office of Iron Range Resources and Rehabilitation, State of Minnesota, in cooperation with the Department of Soil Science, Minnesota Agricultural Experiment Station, Institute of Agriculture, University of Minnesota.

Fox, Robin, Malterer, Thomas, and Zarth, Randee, 1977, Inventory of peat resources in Minnesota: Progress Report, January, 1977, Minnesota Department of Natural Resources, Division of Minerals, $36 \mathrm{p}$.

Heinselman M. L., 1963, Forest site bog processes and peatland types in the Glacial Lake Agassiz Region, Minnesota: Ecological Monographs 33:327-74. , 1970, Landscape evolution, peatland types and the environment in the Lake Agassiz Peatlands Natural Area, Minnesota: Ecology 40:235-61.

Helgesen, J. O., Lindholm, G. F., and Ericson, D. W., 1975, Water resources of the Lake of the Woods watershed, north-central Minnesota: U.S. Geological Survey Hydrologic Investigations Atlas HA-544.

Lindholm, G. F., Helgesen, J. O., and Ericson, D. W., 1976; Water resources of the B1g Fork River watershed, north-central Minnesota: U.S. Geological Survey Hydrologic Investigations Atlas HA-549. 